\title{
On the key role of water in the allylic activation catalysed by Pd (II) bisphosphinite complexes
}

\author{
RAKESH KUMAR SHARMA and ASHOKA G SAMUELSON* \\ Department of Inorganic and Physical Chemistry, Indian Institute of Science, Bangalore 560012 \\ e-mail: ashoka@ipc.iisc.ernet.in
}

\begin{abstract}
Palladium and platinum complexes of bisphosphinites and bisphosphines derived from mandelic acid have been prepared and characterized. Their ability to catalyze allylation of imines with allyltributylstannane has been studied. Bisphophinite complexes of Pd (II) are shown to be ideal and they work best in the presence of one equivalent of water. The near neutral conditions employed make the catalysts suitable for a wide variety of substrates.
\end{abstract}

Keywords. Bisphosphinites; bisphosphines; mandelic acid; allylation; palladium and platinum.

\section{Introduction}

Allylation of carbonyls and imines is an excellent and convenient source of homoallylic alcohols and amines respectively. These are important intermediates in the synthesis of many natural products of great medicinal value. ${ }^{1}$ While homo allylic alcohols are more readily accessible due to the ready allylation of carbonyl compounds, the corresponding route to homo allylic amines via allylation of imines is less favoured due to reduced electrophilicity. ${ }^{2}$ Activation of the imine with a Lewis acid increases its electrophilicity towards the allyl fragment ${ }^{3,4}$ but also promotes the ready hydrolysis of imines which is an unwanted side reaction. Thus the design of a nonLewis acid catalyst for allylic imination is quite a challenge.

A recent report has explored the use of a bis $\pi$-allyl palladium complex ${ }^{5}$ as a catalyst in the presence of phosphines. ${ }^{6}$ The chemical and optical yields reported in that study, encouraged us to seek a better method for catalytic allylation of imines.

We report here the synthesis of a new series of catalysts based on phosphinites, readily generated from the alcohols and $\mathrm{PPh}_{2} \mathrm{Cl}$; metal coordinated or otherwise.

They promote the allylation of imines using allyltributlystanane as the source of the allylic fragment. The reaction is best carried out in the presence of one equivalent of water but is in no way unique as it has been observed in other systems as well. ${ }^{7}$ The catalyst system described here, results in considerably improved yields. Although chiral forms of the catalysts are readily accessible from the available chiral pool of alcohols, optical yields are disappointingly low.

\section{Results and discussion}

The complexes described here were readily generated from the bisdiphenylphosphinyl chloride complex cis- $\left[\mathrm{MCl}_{2}\left(\mathrm{PPh}_{2} \mathrm{Cl}\right)_{2}\right](2)$ which in turn can be obtained from the reaction of $\mathrm{PPh}_{2} \mathrm{Cl}$ with $\left[\mathrm{MCl}_{2}(1,5-\mathrm{COD})\right]$ $(\mathrm{M}=\mathrm{Pd} / \mathrm{Pt})(\mathbf{1})$. Treatment of (2) with alcohols in situ generates phosphinite complexes of $\mathrm{Pd} / \mathrm{Pt}$. A range of alcohols, diols, chiral and achiral could be used in this reaction. Diols capable of chelation permitted isolation of molecular complexes which could be readily characterized. However, diols oriented in a trans fashion led to polymeric molecules and did not afford discrete molecules.

Preparation of diphosphinites followed the procedure reported by Bergamini and coworkers. ${ }^{8}$ Once coordinated to the metal, the bisphosphintes were found to be quite stable. Thus chiral 1,2-diols such as phenyl glycol derived from reduction of optically

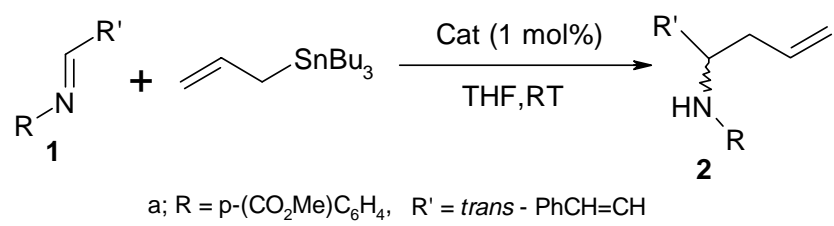

Figure 1. 


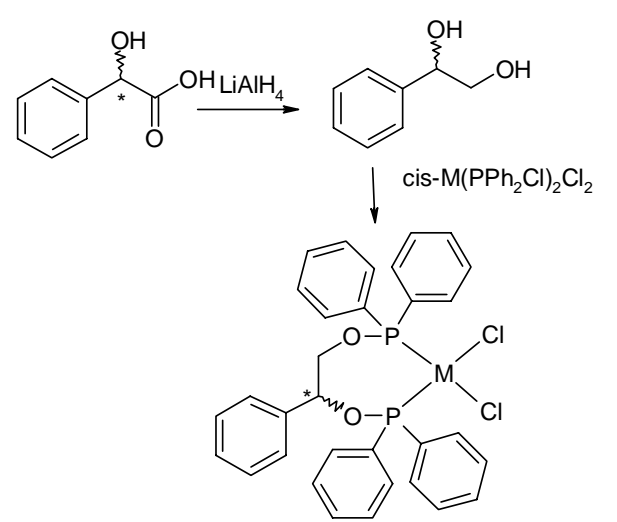

I, $\mathrm{R}$ isomer III, $\mathrm{S}$ isomer $(\mathrm{M}=\mathrm{Pd})$

II, $\mathrm{R}$ isomer $\mathbf{I V}, \mathrm{S}$ isomer $(\mathrm{M}=\mathrm{Pt})$

Scheme 1.
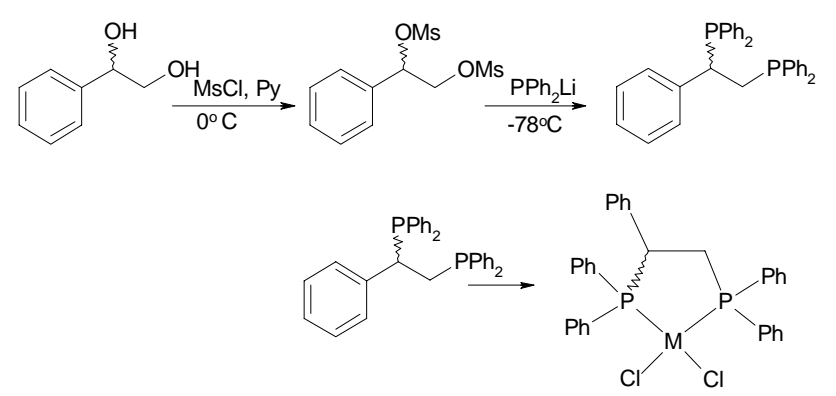

$\mathbf{V}$; $\mathrm{R}$ isomer $(\mathrm{M}=\mathrm{Pd}) \quad \mathrm{VI}$; $\mathrm{R}$ isomer $(\mathrm{R}=\mathrm{Pt})$

VII; $S$ isomer $(M=P d) \quad$ VIII; $S$ isomer $(R=P t)$

Scheme 2.

pure mandelic acid $^{9}$ were used in this study to obtain optically pure complexes.

The corresponding bisphosphines were also conveniently synthesised by reaction of the methanesulphonates derived from optically active phenyl glycols with $\mathrm{PPh}_{2} \mathrm{Li}^{14}$.

\subsection{Catalytic allylation and the influence of water}

Initial tests were carried out on the allylation of imines derived from cinnamaldehyde using allyltributylstannane with 10 mol percentage of the catalyst (table 1). Surprisingly, when the most active catalyst was tested using smaller quantity $(1 \mathrm{~mol} \%)$, the reaction was faster. However, the reaction was not accelerated further when, $0 \cdot 1 \mathrm{~mol} \%$ of catalyst was used. No further attempts were made to optimise the amount of catalyst. A second surprise we encountered in this reaction was its reaction in the presence of water. With $1 \mathrm{~mol} \%$ of the catalyst, the reaction was com- plete in $8 \mathrm{~h}$, if one equivalent of water was present. This represented considerable acceleration over the reaction conducted in the absence of water (entry 3 table 1 and entry 1 table 2) Using greater than one equivalent of water was detrimental to the yield as it led to hydrolysis of imine. We attempted the catalysis of the reaction with complexes having triarylphosphines instead of the phosphinites and found them ineffective.

Attempts to extend the reaction to allylation of aldehydes were not very successful as catalyst decomposition was observed during the reaction. In order to study the electronic demands on the allylation, electron-withdrawing and electron-donating substituents were used on the amine and aldehyde that went into the making of the imine. The results are given in table 3 . The maximum yields and minimum reaction times were observed with electron withdrawing substituents.

Based on the advantage provided by electron withdrawing groups, we propose nucleophilic allylation of a Pd coordinated imine. This would suggest a six-membered intermediate shown in scheme 4 . Since one equivalent of water is required, a stoichiometric reaction of one of the intermediates is a key step. One possible role for water could be the liberation of the active form of the catalyst from the product-complexed-catalyst. Surprisingly, under similar conditions, the platinum complexes were found to be ineffective.

\section{Experimental section}

All reactions and manipulations were routinely performed under a dry nitrogen atmosphere by using standard Schlenk techniques. Tetrahydrofuran and diethyl ether were doubly distilled over sodium/ benzophenone and $\mathrm{LiAlH}_{4}$. Dichloromethane was purified by distillation from $\mathrm{P}_{2} \mathrm{O}_{5} \cdot \mathrm{PPh}_{2} \mathrm{Cl}$ was purified by distillation under nitrogen prior to use. ${ }^{1} \mathrm{H}$ and ${ }^{31} \mathrm{P}$ NMR spectra were recorded on Bruker AMX $400 \mathrm{MHz}$ spectrometer. Peak positions are given in ppm relative to TMS $\left({ }^{1} \mathrm{H}\right)$ and to external $\mathrm{H}_{3} \mathrm{PO}_{4}$ $\left({ }^{31} \mathrm{P}\right)$. Elemental analyses $(\mathrm{C}, \mathrm{H}, \mathrm{N})$ were performed using Thermo Finnigan FLASH EA 1112 analyser. Optical rotations were obtained on a Jasco DIP-370 instrument.

Literature methods were used for preparation of $\left[\mathrm{PtCl}_{2}(1,5-\mathrm{COD})\right]^{11}$ and $\left[\mathrm{PdCl}_{2}(1,5-\mathrm{COD})\right]^{12}$. Catalysts V-VIII were made according to literature procedure. ${ }^{13}$ All complexes were recrystallized from dichloromethane/diethyl ether. 
Table 1. Allylation of imine 1a.

\begin{tabular}{ccccc}
\hline Entry & Catalyst & $\begin{array}{c}\text { Reaction time } \\
(\mathrm{h})\end{array}$ & $\begin{array}{c}\text { Isolated yield } \\
(\%)\end{array}$ & $\begin{array}{c}\text { Catalyst amount } \\
(\mathrm{mol} . \%)\end{array}$ \\
\hline 1 & I & 24 & 77 & 10 \\
2 & II & $42^{*}$ & 40 & 10 \\
3 & III & 24 & 88 & 10 \\
4 & IV & 48 & 37 & 10 \\
5 & V & 36 & 82 & 10 \\
6 & VI & 72 & 00 & 10 \\
7 & VII & 38 & 86 & 10 \\
8 & VIII & 72 & 00 & 10 \\
9 & I & 16 & 94 & 1 \\
10 & I & 80 & 92 & $0 \cdot 1$ \\
11 & III & 17 & 87 & 1 \\
\hline
\end{tabular}

*Including $36 \mathrm{~h}$ at RT followed by $6 \mathrm{~h}$ of reflux

Table 2. Effect of water.

\begin{tabular}{lccccc}
\hline Entry & Catalyst & $\begin{array}{c}\text { Reaction time } \\
(\mathrm{h})\end{array}$ & Water & $\begin{array}{c}\text { Isolated yield } \\
(\%)\end{array}$ & $\begin{array}{c}\text { Catalyst amount } \\
(\text { mol. \%) }\end{array}$ \\
\hline 1 & III & 14 & $1 \mathrm{eq}$ & 89 & $(10)$ \\
2 & III & 8 & $1 \mathrm{eq}$ & 95 & $(1 \cdot 0)$ \\
3 & III & 37 & $1 \mathrm{eq}$ & 93 & $(0 \cdot 1)$ \\
4 & III & 13 & Excess & 83 & $(1 \cdot 0)$ \\
\hline
\end{tabular}

Standard reaction condition: To a solution of $\mathbf{1 a}(0.07 \mathrm{mmol})$ in dry THF allyltributylstannane $(0.09 \mathrm{mmol})$ was added and stirred for $10 \mathrm{~min}$ at RT. Catalyst III ( $1 \mathrm{~mol} \%$ ) was added followed by degassed water (1 equiv) and the reaction mixture stirred for the given time. The product was separated by column chromatography

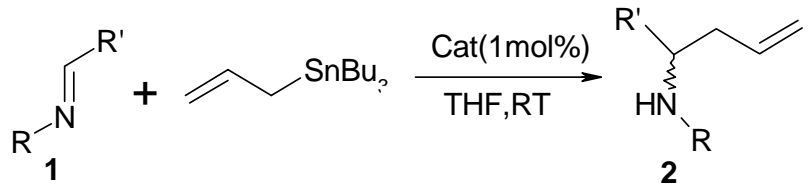

a: $\mathrm{R}=p-(\mathrm{COOMe}) \mathrm{C}_{6} \mathrm{H}_{4}, \mathrm{R}^{\prime}=$ trans $-\mathrm{PhCH}=\mathrm{CH} ; \quad \mathrm{b}: \mathrm{R}=\mathrm{Ph}$, $\mathrm{R}^{\prime}=\mathrm{Ph} ; \mathrm{c} ; \mathrm{R}=\mathrm{p}-\mathrm{C}_{6} \mathrm{H}_{4}(\mathrm{OMe}), \mathrm{R}^{\prime}=\mathrm{Ph} ; \mathrm{d} ; \mathrm{R}=p-\mathrm{C}_{6} \mathrm{H}_{4}\left(\mathrm{CO}_{2} \mathrm{Me}\right)$, $\mathrm{R}^{\prime}=\mathrm{h} ; \mathrm{e} ; \mathrm{R}=\mathrm{Ph}, \mathrm{R}^{\prime}=\mathrm{p}-\mathrm{C}_{6} \mathrm{H}_{4}\left(\mathrm{NO}_{2}\right) ; \mathrm{f} ; \mathrm{R}=p-\mathrm{C}_{6} \mathrm{H}_{4}(\mathrm{OMe})$, $\mathrm{R}^{\prime}=p-\mathrm{C}_{6} \mathrm{H}_{4}\left(\mathrm{NO}_{2}\right) ; \mathrm{g} ; \mathrm{R}=\mathrm{p}-\mathrm{C}_{6} \mathrm{H}_{4}\left(\mathrm{CO}_{2} \mathrm{Me}\right), \mathrm{R}^{\prime}=p-\mathrm{C}_{6} \mathrm{H}_{4}\left(\mathrm{NO}_{2}\right) ;$ $\mathrm{h} ; \mathrm{R}=\mathrm{Ph}, \mathrm{R}^{\prime}=p-\mathrm{C}_{6} \mathrm{H}_{4}(\mathrm{OMe}) ; \mathrm{i} ; \mathrm{R}=p-\mathrm{C}_{6} \mathrm{H}_{4}(\mathrm{OMe}), \mathrm{R}^{\prime}=p-$ $\mathrm{C}_{6} \mathrm{H}_{4}(\mathrm{OMe}) ; \mathrm{j} ; \mathrm{R}=p-\mathrm{C}_{6} \mathrm{H}_{4}\left(\mathrm{CO}_{2} \mathrm{Me}\right), \mathrm{R}^{\prime}=p-\mathrm{C}_{6} \mathrm{H}_{4}(\mathrm{OMe}) ; \mathrm{k}$; $\mathrm{R}=\mathrm{Ph}, \mathrm{R}^{\prime}=$ trans $-\mathrm{PhCH}=\mathrm{CH} ; 1 ; \mathrm{R}=p-\mathrm{C}_{6} \mathrm{H}_{4}(\mathrm{OMe}), \mathrm{R}^{\prime}=$ trans $\mathrm{PhCH}=\mathrm{CH}$.

\section{Scheme 3.}

(A); (R)-(-)-Phenylethane-1,2-diol. A solution of (-)-(R)-mandelic acid (1 g, $6.57 \mathrm{mmol})$ in dry diethyl ether $(20 \mathrm{ml})$ was added dropwise to a stirred suspension of LAH (1.49 g, 39.43 mmol) in diethyl ether $(20 \mathrm{ml})$ at $15^{\circ} \mathrm{C}$ over a period of $2 \mathrm{~h}$. After the addition was complete, the reaction mixture was refluxed for $3 \mathrm{~h}$ and cooled in an ice bath. Dilute $\mathrm{HCl}$ was cautiously added to the stirred solution till the
$\mathrm{pH}$ was between 4 and 5 . The resulting suspension was passed through celite and washed with diethyl ether $(50 \mathrm{ml})$. The diethyl ether solution was dried over sodium sulphate and then concentrated to give $0.85 \mathrm{~g}$ (93\%) (lit., ${ }^{14} 71 \%$ ) of (R)-(-) $-\mathrm{C}_{6} \mathrm{H}_{5} \mathrm{CHOH}$ $\mathrm{CH}_{2} \mathrm{OH}$. Recrystallisation from toluene-hexane $(1: 2)$ gave colourless plates, m.p. $66-67^{\circ} \mathrm{C} ;[\alpha]^{22}{ }_{\mathrm{D}}-39 \cdot 2^{\circ}$ (c $4 \cdot 0, \mathrm{EtOH}) ;{ }^{1} \mathrm{H} \mathrm{NMR}\left(\mathrm{CDCl}_{3}\right) \delta 7 \cdot 31(m, 5 \mathrm{H}$, $\left.\mathrm{C}_{6} \mathrm{H}_{5}\right), 4.80(q, 1 \mathrm{H}, \mathrm{CH}), 3.68\left(m, 2 \mathrm{H}, \mathrm{CH}_{2}\right), 2.90$ $(b r, 1 \mathrm{H}, \mathrm{OH}), 2 \cdot 48(b r, 1 \mathrm{H}, \mathrm{OH}) ;{ }^{13} \mathrm{C} \mathrm{NMR}\left(\mathrm{CDCl}_{3}\right)$ $\delta 140 \cdot 5,128 \cdot 5,127 \cdot 9,126 \cdot 1,74 \cdot 7,68 \cdot 0$.

A completely analogous procedure was used to convert S-(+)-mandelic acid into (B); $\mathrm{S}-(+)$ $\mathrm{C}_{6} \mathrm{H}_{5} \mathrm{CHOHCH}{ }_{2} \mathrm{OH},[\alpha]^{22}{ }_{\mathrm{D}}+38 \cdot 6^{\circ}$ (c 4.0, EtOH).

\subsection{Preparation of catalyst}

(I); R-(-)-Ph( $\left.\mathrm{OPPh}_{2}\right) \mathrm{CHCH}_{2}\left(\mathrm{OPPh}_{2}\right) \mathrm{PdCl}_{2}$ : A typical procedure for making the catalyst is as follows. A solution of $\mathrm{PPh}_{2} \mathrm{Cl}(0.128 \mathrm{ml}, 0.735 \mathrm{mmol})$ in dry degassed THF (2 ml) was added dropwise to a stirred solution of $\left[\mathrm{PdCl}_{2}(1,5-\mathrm{COD})\right](0 \cdot 1 \mathrm{~g}, 0.350 \mathrm{mmol})$ in 
THF (5 ml) at room temperature under nitrogen. A yellow suspension of $\left[\mathrm{PdCl}_{2}\left(\mathrm{PPh}_{2} \mathrm{Cl}\right)_{2}\right]$ was formed which was not isolated. An aliquot of the suspension was evacuated to dryness and dissolved in dry $\mathrm{CDCl}_{3}$ to confirm formation of the complex $\left[\mathrm{PdCl}_{2}\left(\mathrm{PPh}_{2} \mathrm{Cl}\right)_{2}\right]$ ${ }^{31} \mathrm{P}$ NMR (95.8 ppm). ${ }^{8}(\mathrm{R})$-(-)-phenylethane-1,2-diol ( $0.048 \mathrm{~g}, 0.350 \mathrm{mmol}$ ) was added (in $2 \mathrm{ml} \mathrm{THF}$ ) to the reaction mixture and stirred for $12 \mathrm{~h}$. A light yellow precipitate separated out. The reaction mixture was concentrated to half the volume and dry diethyl ether $(20 \mathrm{ml})$ was added to complete the precipitation with stirring for one more hour. The precipitate was filtered and washed with diethyl ether, and dried in a

Table 3.

\begin{tabular}{|c|c|c|c|c|}
\hline Entry & Imine 1 & $\begin{array}{l}\text { Reaction } \\
\text { time }(\mathrm{h})\end{array}$ & $\begin{array}{c}\text { Isolated } \\
\text { yield } 2(\%)\end{array}$ & $\begin{array}{c}\text { Ref. } \\
\text { (product 2) }\end{array}$ \\
\hline 1 & $1 \mathrm{a}$ & 8 & 95 & 6 \\
\hline 2 & $1 b$ & 50 & $63 *$ & 5 \\
\hline 3 & $1 \mathrm{c}$ & 40 & 89 & 5 \\
\hline 4 & $1 d$ & 9 & 96 & 6 \\
\hline 5 & $1 \mathrm{e}$ & 17 & 88 & 6 \\
\hline 6 & $1 \mathrm{f}$ & 8 & 90 & 8 \\
\hline 7 & $1 \mathrm{~g}$ & 9 & 96 & 6 \\
\hline 8 & $1 \mathrm{~h}$ & 30 & 95 & 9 \\
\hline 9 & $1 \mathrm{i}$ & 24 & 80 & 4 \\
\hline 10 & $1 \mathrm{j}$ & 20 & 93 & 6 \\
\hline 11 & $1 \mathrm{k}$ & 17 & 85 & 10 \\
\hline 12 & 11 & 12 & 93 & 4 \\
\hline
\end{tabular}

*Based on ${ }^{1} \mathrm{H}$ NMR. The reaction was run on a $10 \mathrm{mg}$ scale, the ratio of reagents was allylstannanes/imine $\mathbf{1}$ catalyst III $=1 \cdot 2 / 1 / 0 \cdot 01$ in $1 \mathrm{ml} \mathrm{THF}$ at $25^{\circ} \mathrm{C} *$ Complete conversion of imine was not observed even at $50 \mathrm{~h}$

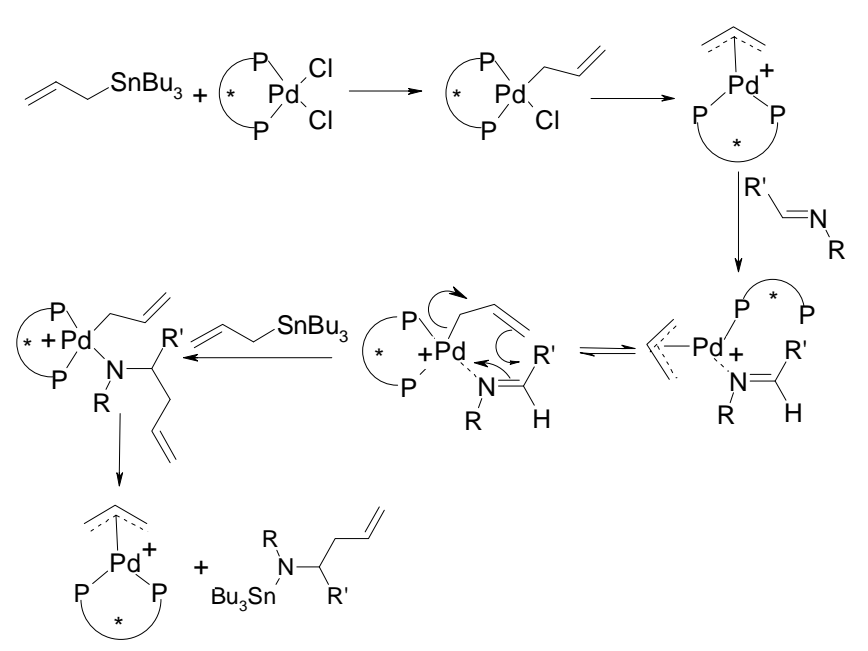

Scheme 4. vacuum desiccator for $12 \mathrm{~h}(0 \cdot 195 \mathrm{~g}, 81 \%) . \mathrm{C}_{32} \mathrm{H}_{28} \mathrm{P}_{2} \mathrm{O}_{2}$ $\mathrm{PdCl}_{2} \cdot \mathrm{CH}_{2} \mathrm{Cl}_{2}$ calcd for $\mathrm{C} 51.55, \mathrm{H} 3.93$ found $\mathrm{C}$ 50.50, H 3.79. $\left.[\alpha]^{25}-42 \cdot 6^{\circ}(c) 1 \cdot 0, \mathrm{CHCl}_{3}\right) ;{ }^{1} \mathrm{H}$ NMR $\left(400 \mathrm{MHz}, \mathrm{CDCl}_{3}\right) \delta 7 \cdot 06-8.08(m, 20 \mathrm{H}, \mathrm{Ph})$ $5.84(m, 1 \mathrm{H}, \mathrm{CHOP}) 4.11(\mathrm{~m}, 1 \mathrm{H}, \mathrm{CHHOP}) 3.89(\mathrm{~m}$, $1 \mathrm{H}, \mathrm{CHHOP}) .{ }^{31} \mathrm{P}$ NMR $\left(162.02 \mathrm{MHz}, \mathrm{CDCl}_{3}\right) \delta$ $125 \cdot 2(d)$ and $113 \cdot 1(d),{ }^{2} J_{\mathrm{PP}}=35 \cdot 6 \mathrm{~Hz}$.

(II); $\mathrm{R}-(-)-\mathrm{Ph}\left(\mathrm{OPPh}_{2}\right) \mathrm{CHCH}_{2}\left(\mathrm{OPPh}_{2}\right) \mathrm{PtCl}_{2}$ : Complex $\left[\mathrm{PtCl}_{2}\left(\mathrm{PPh}_{2} \mathrm{Cl}\right)_{2}\right]$ was prepared by adding $\mathrm{PPh}_{2} \mathrm{Cl}(0.13 \mathrm{~g}, 0.59 \mathrm{mmol})$ to $\left[\mathrm{PtCl}_{2}(\mathrm{COD})\right](0.1 \mathrm{~g}$, $0.27 \mathrm{mmol})$ in dry $\mathrm{THF}^{8,15}(\mathrm{R})-(-)$-Phenylethane1,2-diol (0.036 g, $0.59 \mathrm{mmol})$ also dissolved in THF was added to the reaction mixture and stirred for 30 h. $(0.167 \mathrm{~g}, 80 \%) \mathrm{C}_{32} \mathrm{H}_{28} \mathrm{P}_{2} \mathrm{O}_{2} \mathrm{PtCl}_{2}[\alpha]^{25}{ }_{\mathrm{D}}-45.9^{\circ}$ $\left(c 1 \cdot 0, \mathrm{CHCl}_{3}\right){ }^{1} \mathrm{H}$ NMR $\left(400 \mathrm{MHz}, \mathrm{CDCl}_{3}\right) \delta 7 \cdot 11-$ $7.97(m, 20 \mathrm{H}, \mathrm{Ph}) 6.10(\mathrm{~m}, 1 \mathrm{H}, \mathrm{C}$ HOP $) 4.08(\mathrm{~m}, 1 \mathrm{H}$, CHHOP) $3.92 \quad(m, \quad 1 \mathrm{H}, \quad$ CH $\left(162.02 \mathrm{MHz}, \mathrm{CDCl}_{3}\right) \delta 95.9\left({ }^{1} J_{\mathrm{Pt}-\mathrm{P}}=4105 \mathrm{~Hz}\right)$ and $84 \cdot 5\left({ }^{1} J_{\mathrm{Pt}-\mathrm{P}}=3914 \mathrm{~Hz}\right)$.

(III); $\mathrm{S}-(+)-\mathrm{Ph}\left(\mathrm{OPPh}_{2}\right) \mathrm{CHCH}_{2}\left(\mathrm{OPPh}_{2}\right) \mathrm{PdCl}_{2}$ : Prepared used for preparing (I) $\mathrm{C}_{32} \mathrm{H}_{28} \mathrm{P}_{2} \mathrm{O}_{2} \mathrm{PdCl}_{2}(83 \%)$ $[\alpha]^{23}{ }_{\mathrm{D}}-40 \cdot 1^{\circ}\left(c 1 \cdot 0, \mathrm{CHCl}_{3}\right){ }^{1} \mathrm{H}$ NMR $(400 \mathrm{MHz}$, $\left.\mathrm{CDCl}_{3}\right) \delta 7 \cdot 06-8.01(m, 20 \mathrm{H}, \mathrm{Ph}) 5.84(m, 1 \mathrm{H}, \mathrm{C} \underline{\mathrm{HOP}})$ 4.09 ( $m, 1 \mathrm{H}, \mathrm{C}$ HHOP) 3.90 ( $m, 1 \mathrm{H}, \mathrm{CH} \underline{\mathrm{HOP}}) .{ }^{31} \mathrm{P}$ NMR $\left(162.02 \mathrm{MHz}, \mathrm{CDCl}_{3}\right) \delta 125 \cdot 2(d)$ and $113.2(d)$, ${ }^{2} J_{\mathrm{PP}}=35 \cdot 6 \mathrm{~Hz}$.

(IV); $\mathrm{S}-(+)-\mathrm{Ph}\left(\mathrm{OPPh}_{2}\right) \mathrm{CHCH}_{2}\left(\mathrm{OPPh}_{2}\right) \mathrm{PtCl}_{2}$ : Prepared by similar procedure described for preparation of (II) $(87 \%) \mathrm{C}_{32} \mathrm{H}_{28} \mathrm{P}_{2} \mathrm{O}_{2} \mathrm{PtCl}_{2}[\alpha]^{25}{ }_{\mathrm{D}}+47.2^{\circ}$ (c 1.0, $\left.\mathrm{CHCl}_{3}\right)^{1} \mathrm{H}$ NMR (400 MHz, $\left.\mathrm{CDCl}_{3}\right) \delta 7 \cdot 11-8 \cdot 01(\mathrm{~m}$, $20 \mathrm{H}, \mathrm{Ph}) 6.09(m, 1 \mathrm{H}, \mathrm{C} \underline{\mathrm{HOP}}) 4.10(m, 1 \mathrm{H}, \mathrm{C} \underline{\mathrm{H}} \mathrm{HOP})$ $3.91(m, 1 \mathrm{H}, \mathrm{CH} \underline{\mathrm{HOP}}) .{ }^{31} \mathrm{P}$ NMR $(162.02 \mathrm{MHz}$, $\left.\mathrm{CDCl}_{3}\right) \delta 95 \cdot 9\left({ }^{1} J_{\mathrm{Pt}-\mathrm{P}}=4105 \mathrm{~Hz}\right)$ and $84.5\left({ }^{1} J_{\mathrm{Pt}-\mathrm{P}}=\right.$ $3920 \mathrm{~Hz})$.

\subsection{Catalytic reactions}

Allylation of imines: N-(4-Methoxycarbonyl)phenyl)1-phenyl-1,5-hexadien-3-ylamine (2a); A typical procedure for allylation is as follows. Imine 1a (20 mg, 0.0754 mmol) was dissolved in dry degassed THF in a round-bottom flask under nitrogen. Allyltributylstannane $(28 \mu \mathrm{L}, 0.09 \mathrm{mmol})$ was added and the mixture was stirred for $10 \mathrm{~min}$ before the catalyst, palladium complex I $(0.5 \mathrm{mg}, 0.754 \mu \mathrm{mol})$ was added under nitrogen. The mixture was stirred at room temperature and the reaction progress monitored by TLC. On completion, the reaction mixture was passed through a silica gel column. Elution using $10 \%$ ethyl acetate in petroleum ether gave a light yellow thick liquid, (21 mg, 91\%), $[\alpha]^{23}{ }_{\mathrm{D}}+10 \cdot 8^{\circ},{ }^{1} \mathrm{H}$ 
NMR (400 MHz, $\left.\mathrm{CDCl}_{3}\right) \delta 7 \cdot 83(d, 2 \mathrm{H}, J=8 \cdot 8 \mathrm{~Hz})$, $7.28(m, 5 \mathrm{H}), 6.59(d, 2 \mathrm{H}, J=8.8 \mathrm{~Hz}), 6.55(d, 1 \mathrm{H}$, $J=16 \cdot 4 \mathrm{~Hz}), 6 \cdot 17(d d, J=15 \cdot 6,5 \cdot 6,1 \mathrm{H}), 5 \cdot 83(\mathrm{~m}$, $1 \mathrm{H}), 5.19(m, 2 \mathrm{H}), 4.29(b r, 1 \mathrm{H}), 4.14(d, 1 \mathrm{H}$, $J=5 \cdot 2 \mathrm{~Hz}), 3 \cdot 83(s, 3 \mathrm{H}), 2 \cdot 50(m, 2 \mathrm{H})$.

\section{Conclusion}

We have prepared a series of new bisphosphinite complexes of Pd (II) and Pt (II) derived from optically pure mandelic acids. The utility of these complexes were investigated in the allylation of diverse imines. We have found that addition of one equivalent of water reduces the reaction time. The Pdcatalysed allylation proceeds under essentially neutral conditions. The reactions tolerate a variety of functional groups making it a useful catalyst system.

At this stage we can only provide a tentative role for water in the rate enhancement. It is probably required for the formation of the active form of the catalyst. Further investigations are in progress to probe this role.

\section{Acknowledgements}

We gratefully acknowledge the financial support received from Department of Science and Technology New Delhi.

\section{References}

1. (a) Yamamoto Y and Asao N 1993 Chem. Rev. 93 2207; (b) Roush W R 1991 in Comprehensive organic synthesis (ed.) C H Heathcock (Pergamon Press: Oxford) vol 2, pp 1-53

2. Bloch R 1998 Chem. Rev. 981407

3. (a) Kobayashi S and Ishitani H 1999 Chem. Rev. 99 1069; (b) Akiyama T, Iwai J, Onuma Y and Kagoshima H 1999 Chem. Commun. 2191; (c) Shibata I, Nose K, Sakamoto K, Yasuda M and Baba A 2004 J. Org. Chem. 692185

4. Shimazu M, Masanari K, Watanabe T and Tamaru Y 2005 Org. Lett. 7637

5. (a) Nakamura $\mathrm{H}$, Nakamura $\mathrm{K}$ and Yamamoto $\mathrm{Y}$ 1998 J. Am. Chem. Soc. 120 4242; (b) Nakamura H, Nakamura K and Yamamoto Y 1999 J. Org. Chem. 64 2614; Nakamura H, Iwama H and Yamamoto Y 1996 J. Am. Chem. Soc. 1186641

6. Baskaran S, Islam I, Vankar P S and Chandrasekaran S 1990 J. Chem. Soc., Chem. Commun. 1670

7. Bergamini P, Bertolasi V, Cattabriga M, Ferretti V, Loprieno U, Mantovani N and Marvelli L 2003 Eur. J. Inorg. Chem. pp 918-925

8. Aspinall H C, Bissett J S, Greeves $\mathrm{N}$ and Levin D 2002 Tetrahedron Lett. 43323

9. Andrews P C, Peatt A C and Raston C L 2004 Tetrahedron Lett. 45343

10. Drew D and Doyle J R 1990 Inorg. Synth. 28346

11. Drew D and Doyle J R 1972 Inorg. Synth. 1347

12. Morandini F, Consiglio G and Piccolo O 1982 Inorg. Chim. Acta 5715

13. Brown J M and Murrer B A 1982 J. Chem. Soc. Perkin Trans. II 489

14. Dyer P W, Fawcett J, Hanton M J, Kemmitt R D W, Padda R and Singh N 2003 Dalton Trans. 104 